ENTREPRENEURSHIP AND SUSTAINABILITY ISSUES

ISSN 2345-0282 (online) http://jssidoi.org/jesi/

2020 Volume 7 Number 3 (March)

http://doi.org/10.9770/jesi.2020.7.3(45)

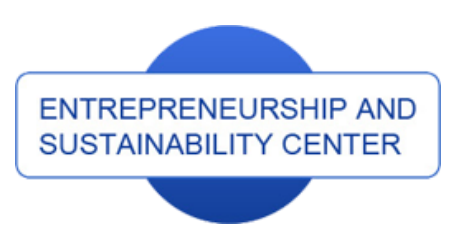

Publisher

http://jssidoi.org/esc/home

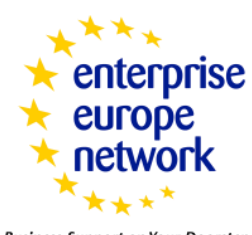

Business Support on Your Doorstep

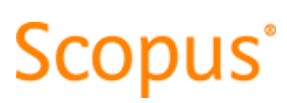

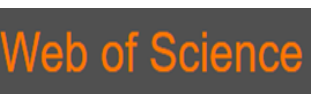

1) Clarivate

\title{
DOES CORPORATE GOVERNANCE AFFECT FINANCIAL REPORTING QUALITY OF POLITICALLY CONNECTED FIRMS?*
}

\author{
Lela Nurlaela Wati ${ }^{1}$, Ramdany $^{2}$, Momon $^{3}$ \\ 1,2,3 STIE Muhammadiyah Jakarta, Jalan Minangkabau No. 60 Jakarta Selatan, Indonesia \\ E-mails: ${ }^{1}$ Lela@stiemj.ac.id ; ${ }^{1}$ lela_nwm@yahoo.com; ${ }^{2}$ Ramdany2012@gmail.com; \\ ${ }^{3}$ momon.lesmana@gmail.com
}

Received 18 July 2019; accepted 20 December 2019; published 30 March 2020

\begin{abstract}
Political connections raise the issue of corporate governance in the disclosure of information. The purpose of this study was to examine the effect of political connections, the effectiveness of the board of commissioners and audit committees, and the quality of external audits on the quality of the company's financial statements. Using a sample of large companies in the Indonesian capital market as many as 871 samples. Regression analysis panel data was used for this analysis. It was found that political connections negatively affect on the quality of financial reporting. The quality of financial reporting of a politically connected firm is lower than those of politically unconnected firms. The effectiveness of the board of commissioners and audit committee is not effective enough in carrying out the internal monitoring function in the company. The influence of political connections can contribute to weak corporate governance and contribute to the low quality of financial reporting. The results of this study are expected to be a reference for investors to determine investment preferences in politically connected companies or not. For management, the results of this study are expected to be a consideration in recruiting the board of commissioners and other policies. Policymakers must encourage or mandate companies to disclose clearer information about the company's relationship with government, political parties, or politicians so that investors and all interested parties can use this information to better assess the quality of the company's financial statements. This study is the first trial to examine more comprehensively the role of political connections, the effectiveness of the board of commissioners and audit committee and the impact of external audit on the quality of financial reporting.
\end{abstract}

Keywords: The quality of financial reporting; political connection; good corporate governance mechanism

Reference to this paper should be made as follows: Wati, L. N., Ramdany, Momon. 2020. Does corporate governance affect financial reporting quality of politically connected firms? Entrepreneurship and Sustainability Issues, 7(3), 2126-2143. https://doi.org/10.9770/jesi.2020.7.3(45)

JEL Classifications: M40, M41, M49

Additional disciplines: law; political sciences; sociology; information and communication

\footnotetext{
* This research was supported by the project, which has received funding from the Directorate of General for Strengthening Research and Development, the Ministry of Research and Technology Republic Indonesia. Grant contract number 5/AKM/PNT/2019.
} 


\section{ENTREPRENEURSHIP AND SUSTAINABILITY ISSUES}

ISSN 2345-0282 (online) http://jssidoi.org/jesi/

2020 Volume 7 Number 3 (March)

http://doi.org/10.9770/jesi.2020.7.3(45)

\section{Introduction}

Like two sides of a sword, political connections have positive and negative impacts on companies. On the one hand, political connections are proven to be able to provide preferential treatment and ease in various accesses, such as access to funding (Tian and Cheung, 2013), government procurement contracts, public policy, subsidies and taxes (Wu et al., 2012; Tian and Cheung, 2013), licensing trade (Mobarak and Purbasari; 2005), access to company IPO (Francis et al., 2009), as well as increased performance and value of politically connected companies (Tian and Cheung, 2013; Wati et al, 2016b; Wati, 2017). But on the other hand, political connections also have a negative impact on companies, namely high leverage followed by overinvestment (Wu et al., 2012), falling stock prices and stock returns (Fan et al., 2007), declining performance companies (Leuz and Gee, 2006), and the low quality of financial reporting (Chaney et al., 2011; You and Du, 2012; Yen, 2013; Al-dhamari \& Ku Ismail, 2015; Habib et al., 2018; Lincényi, Čársky, 2020).

Chaney et al. (2011) stated that politically connected companies have lower financial reporting quality compared to companies that are not politically connected, but these companies will still exist in the capital market because they are considered to have a lower cost of debt. Other evidence was also provided by several previous studies that companies with political connections report their financial reporting of low quality to help cover appropriation efforts by not conducting oversight efficiently documented by You and Du, 2012; Yen, 2013; Aldhamari and $\mathrm{Ku}$ Ismail, 2015; Habib et al., 2018. Politically connected companies tend to have opaque financial reporting, which allows them to be involved in rent-seeking (Chi et al., 2019). However, Batta et al. (2014) showed different results where the financial statements of politically connected firms were higher than those of politically unconnected firms.

Political connections raise the issue of corporate governance in the disclosure and disclosure of information (Leuz and Gee, 2006; Mohammed et al., 2017). The high transparency of financial statements will show a variety of provision of subsidies and other special treatments that raise questions of selfish legality that can threaten the establishment that has been provided by politicians or bureaucrats. The phenomenon of state and government officials both active and non-active who sit as independent commissioners, commissioners or even as president commissioners and concurrently independent commissioners in the company, is suspected to be a bridge for companies to obtain the benefits of political connections including various facilities, such as easy access to funding, access obtain government procurement contracts, obtain large subsidies and reduce tax rates, access to trade licensing, security guarantees for corporate investment and other facilities. They ignore good corporate governance where the board of commissioners as a monitoring function for management is used as a venue for seeking political rent. The results of Wati's (2017) research show that the existence of a board of commissioners with active and inactive background and their activities in politically connected companies is quite effective and has an impact on the value of the company both short and long term. This finding indicates that the existence of officials as an independent commissioner or chief commissioner in the company one of the benefits is to become a bridge for companies to obtain the benefits of political connections including various facilities.

Problems related to the poor quality of corporate financial reporting are often addressed by the weakness of corporate governance in the company and / or the weak philosophy of control by management (Beasley, 1996). The independence of the board of commissioners and the characteristics of board expertise are key factors that influence the quality of financial reporting. Companies, which have a high percentage of independent directors, have independent financial directors, and have a larger number of audit committees will produce quality financial and accounting reports (Yao et al., 2012). The audit committee i tasked with assisting the board of commissioners to monitor the financial reporting process by management to increase the credibility of the financial statements. The audit committee provides formal communication between the board, management, external auditors and internal auditors. The effectiveness of an audit committee can be influenced by three characteristics of the board of commissioners, which include competency, several members and activity (Bradbury et al., 2006), Cadbury 


\section{ENTREPRENEURSHIP AND SUSTAINABILITY ISSUES}

ISSN 2345-0282 (online) http://jssidoi.org/jesi/

2020 Volume 7 Number 3 (March)

http://doi.org/10.9770/jesi.2020.7.3(45)

(1995) has focused the composition of the audit committee as an important factor in the quality of financial reporting. Beasly (1996) also states that audit committees that are more independent of management's influence will be better at overseeing the financial reporting process. Dechow et al. (1996) found that the likelihood of accrual discretion was systematically related to weak corporate governance structures and weak management supervision. Chtourou et. al. (2001) examined the relationship between GCG and discretionary accruals and found that the board of directors and audit committees effectively limited the activity of discretionary accruals.

The existence of a qualified external auditor can increase the trust of shareholders and users of financial statements. Therefore, audits conducted with good quality can assure that the audited financial statements are free from material misstatements. Watkins et al. (2004) state that the auditor's reputation associated with supervisory power influences the quality of financial statement information so that the information provided through financial statements reflects the actual financial condition of the company (Chen et al., 2010; Challen, 2011).

Based on this description, this study aims to examine the influence of political connections, the effectiveness of the board of commissioners, the effectiveness of the audit committee and the role of external audits on the quality of the company's financial statements. This study examines more comprehensively political connections in large companies in Indonesia, thus making this study different from previous studies. This study deepens the findings of Beasly, 1996; Beasly et al., 2000; Dechow et al., 1996; Chtourou et al., 2001; Chaney et al., 2011; You and Du, 2012; Yen, 2013; Aldhamari \& Ku Ismail, 2015; Habib et al., 2018; Wati, 2017; Chi et al, 2019 and Jacoby et al. This study combines several independent variables, namely political connections, the effectiveness of the board of commissioners and the audit committee used by previous researchers separately. The effectiveness of the board of commissioners and the audit committee in this study is measured by independence, activity, the board size, education and experience of the board of commissioners and the audit committee as well as the role of the external audit comprehensively on the quality of company reporting. This study uses control variables namely company size, profitability, leverage and age of the company. Robust models use different measurements of the quality of financial statements, Kothari models.

\section{Literature Review}

In this section, we discuss the relations among these factors as studied in the relevant literature and proceed to develop the hypotheses. Political connection theory, resource dependence theory and agency theory are used as theories that underlie this research.

\subsection{The Effect of Political Connections on the Quality of Financial Reporting}

Financial statements have a function as a means of communication between management and users of financial statements. Various information conveyed in the financial statements aims to estimate the value of the company in the future carried out by related parties as a basis for decision making. One of the main information that is of interest to users of financial statements is earnings information. According to Chaney et al. (2011), three things are usually done by politically connected companies on their financial reporting. First is that companies usually take advantage of their political relations by embezzling corporate funds or at least delaying profit reporting with the aim of misleading investors thereby increasing the costs they will incur so that companies are less interested in obtaining foreign funding due to demands for transparency of financial statements will reduce political effects (Leuz et al, 2003; Leuz and Gee, 2006). Second, politically connected companies feel safe from sanctions or penalties for reporting low-quality financial statements, the impact the company will be more careless in terms of presenting a quality financial report. Third, there is a simple reason that every company with low financial reporting quality does tend to form its political relations. These three views can be measured using an accrual quality proxy.

Empirical evidence from the political connections literature shows that the quality of financial reporting of politically connected companies is different from companies that are not politically connected. However, the results of the direction of the influence of political connections on the quality of corporate financial reporting 


\section{ENTREPRENEURSHIP AND SUSTAINABILITY ISSUES}

ISSN 2345-0282 (online) http://jssidoi.org/jesi/

2020 Volume 7 Number 3 (March)

http://doi.org/10.9770/jesi.2020.7.3(45)

vary. On the one hand, career development and bonus motives motivate politically connected company managers to engage in positive or aggressive earnings management (Leuz and Gee, 2006; Chaney et al., 2011; You and Du, 2012), so that politically connected companies show more aggressive earnings management compared to companies that are not connected politically. But on the other hand, politically connected companies can use negative (conservative) earnings management to get government bailouts and negotiate for more government assistance in the form of subsidies (Faccio et al., 2006; Faccio, 2010). Faccio (2010) examined the differences between politically connected and non-politically connected companies in 47 countries. The results show that companies with political connections have higher profit levels and higher market share, this result is supported by Wati et al (2016a) and Wati (2017). However, empirical studies conducted Chaney et al., 2011; You and Du, 2012; Yen, 2013; Aldhamari \& Ku Ismail, 2015; Habib et al., 2018; Jacoby et al., 2019 shows that the performance of financially connected corporate financial statements is lower compared to companies that are not politically connected. Political connections can weaken or limit managerial capacity and increase the potential for fraudulent financial statements. The existence of political connections encourages increasing levels of corruption and exacerbates information asymmetry between investors and managers (Wang et al., 2017; Chen et. al, 2010). Based on the description above, the first hypothesis is made:

\section{$\mathrm{H}_{1}$ : Political connections negatively affect the quality of corporate financial reporting}

\subsection{The Effect of the Effectiveness of the Board of Commissioners on the Quality of Financial Reporting}

Corporate governance is a set of mechanisms that can protect minorities from expropriation by managers and controlling shareholders. The mechanism of controlling corporate governance can be carried out through external and internal mechanisms. The external control mechanism is the control of the company based on the market mechanism while the internal mechanism is the control carried out by the board of commissioners including the committees under it, the board of directors, management and shareholders, or through an attractive and competitive incentive scheme for management (Wati, 2016a; Wati et al., 2017). This study uses an internal mechanism with controls carried out by the board of commissioners and the audit committee as well as the role of the external audit, in this case, the public accounting firm that audits the company's financial statements.

The board of commissioners is one of the main factors of the internal mechanism of corporate governance because the board of commissioners acts as a representative of the owner of the company who oversees management in managing the company. The board of commissioners in carrying out their duties is required to be independent and always pay attention to the interests of the company, and other stakeholders above personal or group interests. In practice in Indonesia, it often happens that members of the board of commissioners do not carry out their very basic supervisory role towards the board of directors. The board of commissioners is often considered to have no benefits, this can be seen in the fact, that many members of the board of commissioners do not have the ability and can not show their independence. In many cases, the board of commissioners also failed to represent the interests of other stakeholders besides the interests of the majority shareholder. The existence of the board of commissioners in the company functions more like a rubber stamp for decisions made by management (Hermawan, 2012; Wati, 2017). This condition occurs because the process of selecting the board of commissioners tends to be less democratic where the candidates for the board of commissioners are often chosen by management so they do not dare to criticize management.

Beasley (1996) concluded that smaller boards will be more effective in supervising actions than larger boards. Chtourou et al. (2001) gave different results, whereby the board of commissioners with large numbers was able to monitor financial reporting more effectively. This indicates that the large size of the board of commissioners can monitor the financial reporting process more effectively than the size of the small board of commissioners. The increasing number of the board of commissioners will be very helpful in its function as supervisor of management performance so that the quality of the financial statements produced can also be managed well (Anderson et al., 2003). Uadiale's research (2010) shows that companies with a large number of board of directors members will be more effective in supervising, to improve the company's financial performance compared to companies that have 


\section{ENTREPRENEURSHIP AND SUSTAINABILITY ISSUES}

ISSN 2345-0282 (online) http://jssidoi.org/jesi/

2020 Volume 7 Number 3 (March)

http://doi.org/10.9770/jesi.2020.7.3(45)

a smaller number of board of directors' members. Wati's findings (2017) support Chtourou et al. (2001), Anderson et al. (2003) and Uadiale (2010) that the greater the number of board of commissioners in the company, the monitoring function will increase, but when using the moderation of political connections, it reverses the direction where the more the number of boards, the monitoring function will decrease. Based on the literature review and previous researches, Hypothesis $2 \mathrm{a}$ is formulated as follows:

\section{H2a: Board of Commissioners size has a positive effect on the quality of financial reporting}

Independent commissioners can act as mediators in disputes that occur between internal managers, oversee management policies, and provide advice to management. An independent commissioner is the best position to carry out the monitoring function to create a company with good governance. The strength of the board of commissioners is shown by the composition of the membership of the independent board of commissioners. Companies that have a large composition of independent directors will prevent management opportunistic behaviour so that they can produce financial reports with better quality financial statements and lower discretionary accruals (Qinghua et al., 2007). Di Donatto and Fiori (2012) also emphasized that the independence of the board of commissioners was a factor that could hamper discretionary accruals. The more the number of independent commissioners, the better the quality of the company's financial reporting. This result is supported by Mohammed et al (2017) which shows that independent commissioners have a positive effect on the level of caution in corporate financial reporting.

Research conducted by Chen et al. (2010) which specifically examines whether the independence, financial expertise and voluntary information of an independent board of directors are related to the absolute value of discretionary accruals. The results state that the independence of the board, the financial competence of the independent directors, and the voluntary formation of the independent board of directors are related to the lower tendency of discretionary accruals or the higher quality of corporate financial reporting. Qin and Liwen (2007) in their research stated that the ability of the board of directors in terms of effective supervision will increase along with the increasing number of an independent board of directors in a company. Klein (2002) also states that an independent board of directors can be more effective in conducting supervision. Besides that, Xie et al. (2003) have empirically proven that independent commissioners and audit committees who are active and knowledgeable about finance are important factors in preventing managers' tendencies to discretionary accruals. Based on the literature review and previous researches, Hypothesis $2 \mathrm{~b}$ is formulated as follows:

\section{H2b: The independent board of commissioners positively influences the quality of financial reporting}

An active board of commissioners will hold regular meetings to find out issues in more detail and earlier so that more systematic supervision can be carried out. The activities of the board of commissioners as measured by the number of meeting frequencies can affect the effectiveness of the board's role in monitoring management actions, particularly concerning the process of presenting financial statements. (Vafeas, 1999), Anderson et al. (2003) and Xie et al. (2003) also states that board activity as measured by meeting frequency can also affect the effectiveness of the board. Research conducted by Brick and Chidambaran (2010) states that board activity includes the frequency of the number of meetings attended by the board and structural changes in the board subcommittees, as well as the activities of the board will determine the level of supervision quality of the board. The frequency of meetings has been widely used as a proxy to measure the activities of the board of commissioners, the higher the frequency of meetings will increase the effectiveness of the board of commissioners. This is because the higher the activities carried out by the board, it will increase the disclosure of information which will ultimately reduce the level of information asymmetry. Based on the literature review and previous researches, Hypothesis $2 \mathrm{c}$ is formulated as follows:

\section{H2c: The activity of the board of commissioners has a positive effect on the quality of financial reporting}

Competence possessed by members of the board of commissioners is a very important factor for the creation of an effective board of commissioners (Cadbury Report, 1992). Competence can be seen from the educational background and experience of members of the board of commissioners. To be able to understand and oversee the 


\section{ENTREPRENEURSHIP AND SUSTAINABILITY ISSUES}

ISSN 2345-0282 (online) http://jssidoi.org/jesi/

2020 Volume 7 Number 3 (March)

http://doi.org/10.9770/jesi.2020.7.3(45)

process of presenting the company's financial statements, it is specifically expected that members of the board of commissioners have knowledge or background in finance and accounting (Hermawan, 2012).

This competence will affect the ability of the board of commissioners in carrying out their functions to conduct oversight optimally. Jeanjean and Stolowy (2009) found that accounting expertise on average was negatively related to the type of board (two-tier versus one-tier) and growth opportunities, and positively related to board independence, ownership concentration and institutional ownership.

The experience possessed by an outside independent board can be reflected in the position or job owned by the person concerned. Experience as a board member in another company, CEO or former CEO of another company, or management consultant will be able to improve the competence of the monitoring role of the outside independent board. It can be concluded that the background knowledge and experience of the board of commissioners will affect the effectiveness of the monitoring role of the board of commissioners. Chtourou et al. (2001), Carcello et. al. (2006), and Hermawan (2012) explained that in addition to the independence of the board of commissioners, expertise (expertise) in the field of accounting and finance proved to be able to limit management in conducting accrual discretion. Xie et al. (2003) support this statement where there is a negative influence from the background of financial knowledge held by the board of commissioners on accrual discretion. This shows that the educational background and experience of the board of commissioners can control and hinder management from conducting accrual discretion, to produce quality financial reports. Based on the literature review and previous researches, Hypothesis $2 \mathrm{~d}$ and $2 \mathrm{e}$ is formulated as follows:

H2d: Board of Commissioners education has a positive effect on the quality of financial reporting H2e: The Board of Commissioners' experience has a positive effect on the quality of financial reporting

\subsection{The Effect of The Effectiveness of The Audit Committee on The Quality of Financial Reporting}

The implementation of good corporate governance will have an impact on the quality of the financial statements produced. Management will find it difficult to manipulate financial statements because of the supervision of the board of commissioners so that the resulting financial statements will be following the actual situation and integrity. Conversely, poor corporate governance will have an impact on the failure of the objectives of the financial statements (Norwani et al, 2011).

To support the duties of the board of commissioners in the company's internal control mechanism, the board of commissioners is assisted by an audit committee so that the effectiveness of the audit committee also affects the quality of the company's financial reporting (Chtourou et al., 2001). In carrying out its duties the audit committee provides formal communication between the board, management, external auditors, and internal auditors. the effectiveness of an audit committee can be influenced by three characteristics which include competence, number of audit members and audit activities (Bradbury et al., 2006). Qinghua et al (2007) produced a study in which the number of audit committees affected the quality of financial statements. This result is supported by Soliman and Ragab (2014), Inaam and Khamoussi (2016) which results that the audit committee influences the quality of the report finance.

Bedard et al., (2004) argue that the greater the audit committee, the more likely it is to uncover and resolve potential problems in the financial reporting process because it is likely to provide the necessary strength and diversity of views and expertise to ensure the effectiveness of monitoring. Klein (2000) produced research on the nonlinear negative relationship between the independence of the audit committee and earnings management. Klein also said that a more independent board structure would be more effective in overseeing the company's financial reporting process. Veronica and Bachtiar (2005), Inaam and Khamoussi (2016) state that the independence characteristics of the audit committee have a negative influence on the likelihood of earnings management. However, Xie et al. (2003) found an insignificant relationship between the number of audit 


\section{ENTREPRENEURSHIP AND SUSTAINABILITY ISSUES}

ISSN 2345-0282 (online) http://jssidoi.org/jesi/

2020 Volume 7 Number 3 (March)

http://doi.org/10.9770/jesi.2020.7.3(45)

committees and earnings management as a measure of the quality of financial statements. Based on the literature review and previous researches, Hypothesis $3 \mathrm{a}$ is formulated as follows:

\section{H3a: Audit committee size has a positive effect on the quality of financial reporting}

Bryan et al. (2004) mention other important characteristics that must be possessed by the audit committee are the frequency of meetings, expertise in finance, and time commitment. These three factors are the key determinants of the effectiveness of the audit committee. This characteristic can influence the financial reporting process. Abbot et al. (2004) found evidence that audit committees that met less than the minimum number were more likely to restate their profits. He also found evidence that fraud and restatement of profits occurred more and more when audit committee members lacked competence in the financial sector. The effectiveness of the audit committee will decrease when its members work in many companies.

They stressed that the experience of working at other companies initially could increase the effectiveness of audit committee members. However, this situation quickly reversed when audit committee members worked in many other companies (more than three companies). The frequency of audit committee meetings as one of the characteristics of the audit committee can affect the quality of the company's financial reporting. An effective audit committee meets regularly to ensure that the financial reporting process is functioning properly, and therefore a well-functioning and active audit committee may prevent earnings management. Previous research conducted by Hermawan (2012), Soliman and Ragab (2014), Inaam and Khamoussi (2016) stated that the higher frequency of meetings conducted by the audit committee its supervisory activities will be higher which causes the high quality of financial statements. Xie et al. (2003) examined the role of the board and audit committee in preventing earnings management practices. As a result, the activities of the board and audit committee (which is proxied by the number of meetings they do) and the superiority of background in their financial fields can be important factors to limit the possibility of managers carrying out earnings management practices. Based on the literature review and previous researches, Hypothesis $3 \mathrm{~b}$ is formulated as follows:

H3b: Audit committee activities have a positive effect on the quality of financial reporting

Chtourou et al. (2001) state that companies that have more active audit committees and boards of commissioners have a negative relationship with earnings management. Chtourou et al. (2010), companies that have more audit committees and have competence in the field of finance and accounting have a negative influence on earnings management. Dhaliwal, et al. (2006) states that the characteristics of the audit committee in the form of accounting, financial and supervisory competencies they have have a positive effect on the quality of the accruals contained in the published financial statements.

The audit committee's financial expertise increases the likelihood that detected material misstatements will be communicated to the audit committee and corrected promptly. Marra et al. (2011) found that audit committee financial expertise has a negative relationship with earnings management. A high level of financial sophistication is needed for audit committee members to increase the effectiveness of the audit committee in monitoring discretionary accruals. This result is supported by Inaam and Khamoussi (2016) where the expertise of the audit committee affects the decline in earnings management and improving the quality of financial statements. Based on the literature review and previous researches, Hypothesis $3 \mathrm{c}$ and $3 \mathrm{~d}$ is formulated as follows:

H3c: Education audit committee has a positive effect on the quality of financial reporting H3d: The experience of the audit committee has a positive effect on the quality of financial reporting

\subsection{The Influence of External Audit on The Quality of Financial Statements}

External auditors are responsible for verifying that the financial statements are fairly stated by GAAP and reflect the company's economic conditions. Thus, external auditor verification adds credibility to the company's financial statements. Qualified external auditors are expected to limit opportunistic earnings management. External auditors with quality audits can increase the confidence of shareholders and users of financial statements because audits conducted with good quality can assure that the audited financial statements are free from material misstatements 


\section{ENTREPRENEURSHIP AND SUSTAINABILITY ISSUES}

ISSN 2345-0282 (online) http://jssidoi.org/jesi/

2020 Volume 7 Number 3 (March)

http://doi.org/10.9770/jesi.2020.7.3(45)

so that the published financial statements are believed to contain no elements of management practice earnings especially accrual earnings management.

Watkins et al. (2004) state that the auditor's reputation which is connected with the supervisory power influences the quality of financial statement information so that the information provided through the financial statements reflects the actual economic situation. Klein (2003) states that big4 auditors can transfer some of their responsibilities to monitor financial reporting to the audit committee. Besides, Big4 auditors can provide higher audit quality for reasons of having many clients, lots of resources, technology, and trained staff for audit work and they don't want to lose their clients due to process violations.

The literature recognizes that the big4 auditors provide higher audit quality and offer greater reliability to client financial statements than non-Big 4 auditors. The results of Ahsen (2011), Soliman and Ragab (2014) show that Big 4 auditors are better at limits earnings management compared to non-Big 4 auditors. They find that clients of non-Big 4 auditors have higher discretionary accrual rates. In the same context, Ahsen (2011) found that Big 4 auditors associate with fewer earnings management in the company. Indeed, Big 4 audit companies are assumed to have higher audit quality than non-Big 4 audits, because they are less dependent on their clients. This is supported by Ahmad et al. (2016) which shows evidence that audit quality in Indonesia influences the decline in earnings management which has an impact on improving the quality of the company's financial statements. Chen et al. (2010) state that good audit quality has a significant effect on accrual earnings management. Challen (2011) also states that audit quality has a significant effect on real earnings management. Johnson et al. (2002) show the results of research in which the size of the accounting firm and the high competence of auditors from public accounting firms allow the quality of the audit report to be better and have an impact on the quality of financial statements.

H4: Audit quality has a positive effect on the quality of financial reporting

\subsection{The Influence of Firm Size, Profitability, Leverage and Firm Age on The Integrity of Financial Statements (Control Variables)}

To control independent variables outside the model, firm size, profitability, leverage and firm age variables are included as control variables to control the effect of independent variables on the integrity of financial statements. This refers to positive accounting theory related to the theory of plan bonus hypotheses, debt covenants and political cost hypotheses (Watts and Zimmerman, 1986).

The size of the company is a value that indicates the size of the company. The greater the company and its area of business resulted in the owner not being able to manage the company himself directly. This is what triggers agency problems. Large companies tend to make earnings management actions smaller than smaller companies because large companies are seen as more critical by outsiders, both by investors, creditors, the government and the public.

Based on the theory and previous research, the author makes the following framework: 


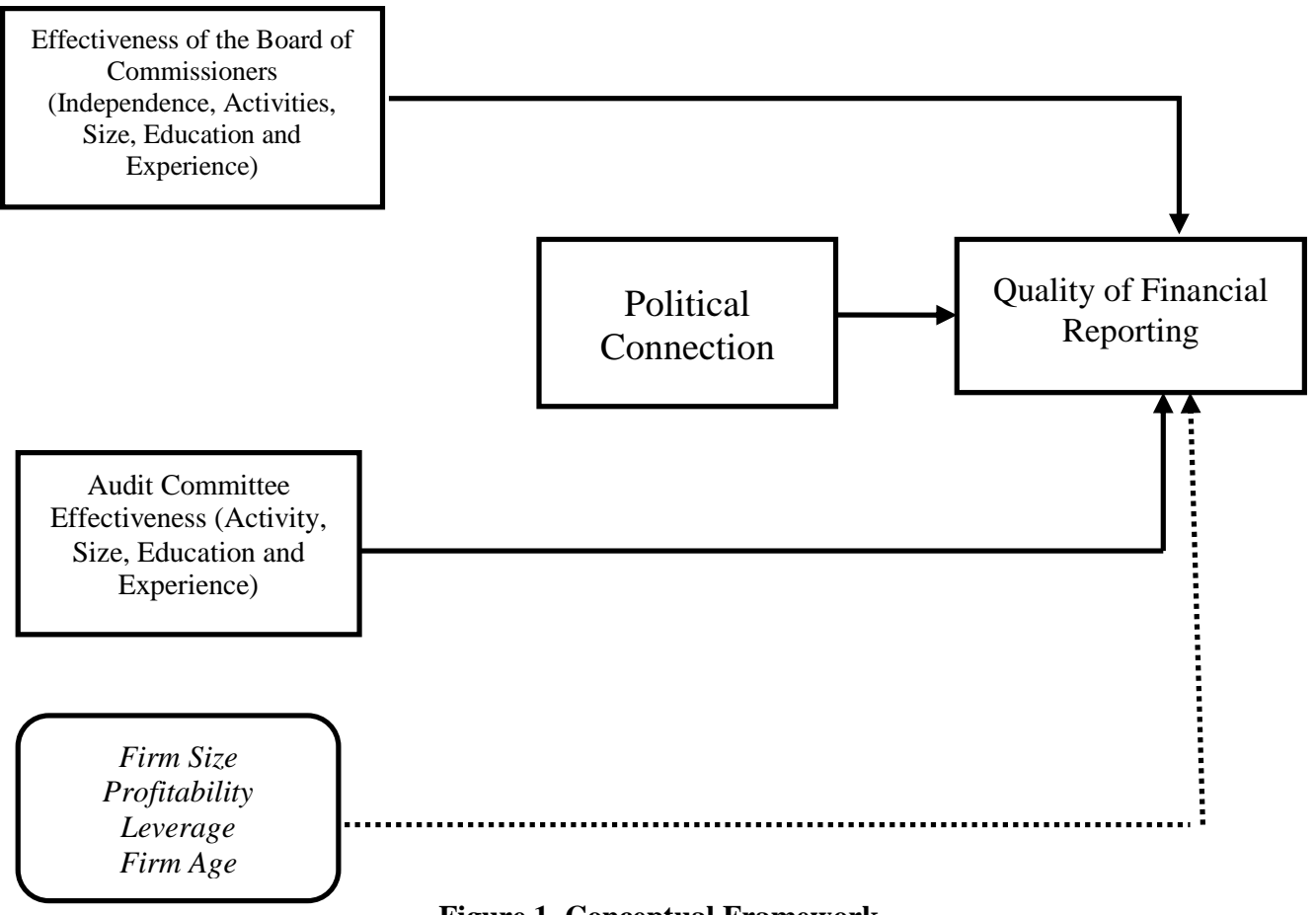

Figure 1. Conceptual Framework

Source: a Literature review

\section{Methodology}

The sample of this research is a large company listed on the Indonesia Stock Exchange since 2005-2017 were 75 companies and which can be processed as many as 67 companies (2005-2017), so the total of observations is 871 samples. The dependent variable in this study is the quality of financial reporting proxied by discretionary accrual using the Jones modified model. The independent variable used is a political connection, Board of commissioners' effectiveness, audit committee effectiveness and audit quality. Board of commissioners' effectiveness consists of board size, independent board, board meeting, board education and board expertise. Audit committee effectiveness consists of audit size, audit meeting, auditor education and auditor expertise. Control variables are firm size, profitability, leverage and firm age.

The discretionary accrual measure used as a comparison to the Jones modified model is the Kothari model. The value of the accrual discretion resulting from earnings management calculations is multiplied by a negative one to ensure that a positive value indicates a higher quality of financial statements. If the discretionary accrual value is positive, then earnings management is done by increasing earnings. If the discretionary accrual value is negative, then earnings management is done by lowering earnings. If the discretionary accrual value is zero, then there is no indication of earnings management.

The political connection uses political connection criteria according to Faccio, 2006; Wati et al, 2016; Wati, 2017. If one of the shareholders of the company or the top management of the company is a member of parliament, ministers or heads of state, or who has a close relationship of them as political party officials, the army and police 
officials. The members of parliament, ministers, or heads of state former included because they still have the power to connect with government. Robust models are used to accrual-based on Kothari models. Table 1 below describes the operational variable:

Table 1. Description of variables

\begin{tabular}{|c|c|}
\hline Variables & Description \\
\hline Dependent: & Modified Jones Model: \\
\hline Discretion Accrual & $\mathrm{TA}_{\mathrm{it}}=\mathrm{NI}_{\mathrm{it}}-\mathrm{CFO}_{\mathrm{it}}$ \\
\hline & $\mathrm{TAC}_{\mathrm{t}} / \mathrm{A}_{\mathrm{t}-1}==\beta_{1}\left(1 / \mathrm{A}_{\mathrm{t}-1}\right)+\beta_{2}\left(\left(\Delta \mathrm{REV}_{\mathrm{t}}\right) / \mathrm{A}_{\mathrm{t}-1}\right)+\beta_{3}\left(\mathrm{PPE} / \mathrm{A}_{\mathrm{t}-1}\right)+\mathrm{e}$ \\
\hline & $\mathrm{NDA}_{t}=\beta_{1}\left(1 / \mathrm{A}_{\mathrm{t}-1}\right)+\beta_{2}\left(\left(\Delta \mathrm{REV}_{\mathrm{t}}-\Delta \mathrm{REC}_{\mathrm{t}}\right) / \mathrm{A}_{\mathrm{t}-1}\right)+\beta_{3}\left(\mathrm{PPE} / \mathrm{A}_{\mathrm{t}-1}\right)$ \\
\hline & $\mathrm{DA}_{\mathrm{t}}=\mathrm{TA} t / \mathrm{A}_{\mathrm{t}-1}-\mathrm{NDA}_{\mathrm{t}}$ \\
\hline \multicolumn{2}{|l|}{ Independent: } \\
\hline Political Connection & Dummy Variable: \\
\hline Board of Commissioners & $1=$ political connected \\
\hline Effectiveness Variables: & $0=$ non political connected \\
\hline Independence Board & The ratio of Independence commissioners board to the amount of BoC \\
\hline Board Size & The amount of commissioners board \\
\hline Board Meeting & The amount of commissioners board Meeting \\
\hline Board Education & The proportion of commissioners education \\
\hline Board Experience & The proportion of commissioners experience \\
\hline \multicolumn{2}{|l|}{ Audit Committee Effectiveness } \\
\hline \multicolumn{2}{|l|}{ Variables: } \\
\hline Audit Size & The amount of audit committee \\
\hline Audit Meeting & The amount of audit committee meeting \\
\hline Audit Education & The proportion of audit committee education \\
\hline Audit Experience & The proportion of audit committee experience \\
\hline \multirow[t]{2}{*}{ Audit quality } & Dummy variable: \\
\hline & $1=$ If the big 4 of accounting public; $0=$ otherwise \\
\hline \multicolumn{2}{|l|}{ Control Variables: } \\
\hline Firm Size & Log of total assets \\
\hline Profitability & The ratio of net profit to total assets \\
\hline Leverage & The ratio of debt to total equity \\
\hline Firm Age & Number of years since incorporation \\
\hline
\end{tabular}

Source: Literature review

To test the hypotheses 1-4 of this study, we used the following regression model:

$$
\begin{aligned}
\mathrm{DA}=\alpha & +\beta_{1} \mathrm{PC}_{\mathrm{it}}+\beta_{2} \mathrm{BOC}_{\mathrm{it}}+\beta_{3} \text { Indepit }_{\mathrm{it}}+\beta_{4} \mathrm{BMeet}_{\mathrm{it}}+\beta_{5} \mathrm{BEduc}_{\mathrm{it}}+\beta_{6} \mathrm{BExpt}_{\mathrm{it}}+\beta_{7} \text { Audit }_{\mathrm{it}}+\beta_{8} \mathrm{AMeet}_{\mathrm{it}} \\
& +\beta_{9} \mathrm{AEduc}_{\mathrm{it}}+\beta_{10} \mathrm{AExp}_{\mathrm{it}}+\beta_{11} \mathrm{Big}_{\mathrm{it}}+\beta_{12} \mathrm{Size}_{\mathrm{it}}+\beta_{13} \mathrm{ROA}_{\mathrm{it}}+\beta_{14} \mathrm{DER}_{\mathrm{it}}+\beta_{15} \mathrm{Age}_{\mathrm{it}}++\varepsilon \ldots \ldots \ldots . . .(1)
\end{aligned}
$$


ENTREPRENEURSHIP AND SUSTAINABILITY ISSUES

ISSN 2345-0282 (online) http://jssidoi.org/jesi/

2020 Volume 7 Number 3 (March)

http://doi.org/10.9770/jesi.2020.7.3(45)

\section{Results \& Discussion}

Table 2. Descriptive statistic of the Variables from 2005-2017

\begin{tabular}{llll}
\hline Variable & Min & Max & Mean \\
\hline Political Connection & 0 & 1 & 0.73 \\
Discretion Accrual (Jones) & -33.05 & 25.78 & 0.03 \\
Discretion Accrual (Kothari) & -33.12 & 25.74 & -0.028 \\
Discretion Accrual Political & -33.05 & 25.78 & 0.108 \\
Discretion Accrual Non- & -17.51 & 5.47 & -0.18 \\
Political & & & \\
Independence & 0.14 & 1 & 0.45 \\
Board Size & 2 & 13 & 5.62 \\
Board Meeting & 2 & 123 & 13.19 \\
Board of Education & 0 & 1 & 0.81 \\
Board Experience & 0 & 1 & 0.94 \\
Audit Size & 2 & 9 & 3.56 \\
Audit Meeting & 1 & 48 & 11.33 \\
Audit Education & 0.25 & 1 & 0.82 \\
Audit Experience & 0.33 & 1 & 0.99 \\
External Audit Big4 & 0 & 1 & 0.64 \\
Firm Size (Log) & 10.93 & 15.05 & 12.99 \\
Profitability & -1.08 & 1.24 & 0.06 \\
Leverage & -31.44 & 25.79 & 1.61 \\
Firm Age & 1 & 64 & 17.59 \\
\hline
\end{tabular}

Source: Data IDX processed, 2019

Based on table 2, the lowest discretional accrual value in politically connected companies is -33.5 and the highest is 25.78 with an average value of 0.108 . These results indicate that both the lowest, highest value and the average of the Accrual Discretion in politically connected companies are higher than companies that are not politically connected. This shows that politically connected companies are very aggressive in managing earnings either by reducing profits or increasing profits.

The high earnings management in politically connected companies indicates poor financial statements. The results of this study support Bushman \& Piotroski, 2006; Piotroski et al. 2004; Leuz \& Gee 2006; Chaney et al., 2011; You and Du, 2012; Yen, 2013; Aldhamari \& Ku Ismail, 2015; Habib et al., 2018; Jacoby et al., 2019 which shows that the quality of financial statements of politically connected firm is lower than those of politically unconnected firms.

The average value of discretional accruals in politically connected companies has a positive value of 0.108 , which means that politically connected companies do earnings management by increasing earnings or overstatement, while companies that are not politically connected do earnings management by lowering profits or accounting conservatism. 
ENTREPRENEURSHIP AND SUSTAINABILITY ISSUES

ISSN 2345-0282 (online) http://jssidoi.org/jesi/

2020 Volume 7 Number 3 (March)

http://doi.org/10.9770/jesi.2020.7.3(45)

Table 3. Regression Analysis Model

\begin{tabular}{lllll}
\hline Variable & Prediction & $\begin{array}{l}\text { Main Model } \\
\text { (Jones) }\end{array}$ & $\begin{array}{l}\text { Robust Model } \\
\text { (Kothari) }\end{array}$ & Result \\
\hline Constant & & $-1.0544^{* * *}$ & $-1.2899^{* * *}$ & \\
Political Connection & $\beta-$ & $-0.1591^{* * *}$ & $-0.1409^{* * *}$ & $\begin{array}{l}\text { Supported } \\
\text { Board Size }\end{array}$ \\
Independence & $\beta+$ & $0.0101^{* *}$ & $0.0097^{* *}$ & Supported \\
Board Meeting & $\beta+$ & $-0.1427^{* *}$ & -0.0849 & Unsupported \\
Board of Education & $\beta+$ & $-0.0034^{* * *}$ & $-0.0024^{* * *}$ & Unsupported \\
Board Experience & $\beta+$ & $-0.0927^{* *}$ & -0.0574 & Unsupported \\
Audit Size & $\beta+$ & -0.136 & -0.1377 & Unsupported \\
Audit Meeting & $\beta+$ & $-0.1206^{* * *}$ & $-0.135^{* * *}$ & Unsupported \\
Audit Education & $\beta+$ & $-0.0021^{*}$ & $-0.0026^{*}$ & Unsupported \\
Audit Experience & $\beta+$ & -0.0567 & 0.0074 & Unsupported \\
External Audit Big4 & $\beta+$ & 0.2663 & 0.3009 & Unsupported \\
Firm Size (Log) & $\beta+$ & $0.1183^{* * *}$ & $0.1329^{* * *}$ & Supported \\
Profitability & $\beta+/-$ & $0.1318^{* * *}$ & $0.1415^{* * *}$ & Supported \\
Leverage & $\beta+/-$ & $-0.588^{* * *}$ & -0.0222 & Supported \\
Firm Age & $\beta+/-$ & $-0.0099^{* *}$ & $0.0081^{* *}$ & Supported \\
$\mathbf{R}^{2}$ & & $-0.0043^{* * *}$ & $-0.0038^{* * *}$ & Supported \\
Adjusted R & & 0.3457 & 0.2925 & 0.2801 \\
statistics & & 0.3342 & $23.4581^{* * *}$ & \\
\hline
\end{tabular}

Source: Data IDX processed, 2019

$* * *$ Significance at $1 \%, * * 5 \%$, and $* 10 \%$

Based on table 3, found that political connections have a significant negative effect on the quality of financial statements of both the Jones model and the Kothari model. The results of this study support the theory of political connection, the theory of resource dependence, where companies will overcome interdependence and uncertainty by establishing connections to the source of interdependency and uncertainty, namely the government, so that building political connections can benefit the company. The results of this study also support previous researchers Leuz \& Oberholzer-Gee, 2006; Chaney et al., 2011; You and Du, 2012; Yen, 2013; Aldhamari \& Ku Ismail, 2015; Habib et al., 2018 which shows that the quality of financial statements of politically connected companies is lower than companies that are not politically connected.

If seen from the mean of the Accrual Discretionary in politically connected companies, the value is positive and greater than companies that are not politically connected. This is an indication that career development interests and bonus motives motivate politically connected company managers to engage in positive earnings management. Political connections can weaken or limit managerial capacity and increase the potential for fraudulent financial statements. The existence of political connections can encourage increased levels of corruption and worsen information asymmetry between investors and managers (Wang et al., 2017; Chen et. al, 2010). These findings also support what Shleifer and Vishny (1994) say, that government intervention in the economy is driven by the need to have control over companies in order to provide jobs, subsidies and other benefits to their supporters, who are expected to provide assistance in the form of votes in elections, funding contributions and bribes. This is due to the very dominant role of government in a country, especially in research discussions in Indonesia.

The results of testing the effect of the effectiveness of the board of commissioners on the quality of financial reporting have no significant effect. Of the five characteristics of the board of commissioners, only the size of the board of commissioners has a significant positive effect on the quality of financial statements. These results indicate that the large size of the board of commissioners can monitor the financial reporting process more 


\section{ENTREPRENEURSHIP AND SUSTAINABILITY ISSUES}

ISSN 2345-0282 (online) http://jssidoi.org/jesi/

2020 Volume 7 Number 3 (March)

http://doi.org/10.9770/jesi.2020.7.3(45)

effectively than the size of the small board of commissioners. Increasing the number of the board of commissioners will be very helpful in its function as a supervisor of management performance so that the quality of the financial statements produced can also be well managed (Chtourou et al., 2001; Anderson et al., 2003; Uadiale, 2010; Wati, 2017).

The test results of the independent board of commissioners and the activity of the board of commissioners have a significant negative effect on the quality of financial statements both by measuring modified Jones and Kothari models. The results of this study do not support agency theory, where independent commissioners and their activities are internal control mechanisms that should prevent management opportunistic behaviour to produce financial reports with better quality financial statements and lower discretion accruals. These results are not following the study of Qinghua et al., 2007; Di Donato and Fiori, 2012; and Mohammed et al., 2017. But support the results of Lara et al. (2007) and Wati (2017) where independent commissioners and board activities in large companies do not affect the performance of the company's financial statements. This empirical evidence shows that the ability of independent commissioners and their activities to monitor will decrease with the increasing size of the independent board of commissioners because it will cause problems in coordination, communication and decision making, especially in large companies. The educational background and experience of the board of commissioners in large companies are unable to control and hinder management from doing accrual discretion, resulting in poor quality financial statements.

The results of testing the effectiveness of the audit committee on the quality of financial statements are also ineffective. The size of the audit committee and the activities of the audit committee have a negative effect on the quality of the company's financial statements. The greater the size of the audit committee and its activities, the less likely it is to uncover and resolve potential problems in the financial reporting process. The results of this study also do not support the internal mechanisms of corporate governance and are in conflict with previous researchers which produced audit committees and their activities have a positive effect on the quality of financial statements (Bédard et al., 2004; Veronica and Bachtiar, 2005; 2013; Soliman and Ragab, 2014; Inaam and Khamoussi, 2016. The ineffective role of the board of commissioners and audit committee in carrying out their monitoring functions in large companies indicates that their existence as an internal mechanism of corporate governance in the company raises a big question mark. These results indicate that the CEO has more power than the board of commissioners and the audit committee. This condition occurs because the process of selecting the board of commissioners tends to be less democratic where the board of commissioners' candidates are often chosen by management so they do not dare to criticize management. Member of the board of commissioners does not have the ability and cannot demonstrate their independence. In many cases, the board of commissioners also failed to represent the interests of other stakeholders other than those of the majority shareholder.

The results of testing the influence of independent commissioners and their activities as well as the size of the audit committee and their activities on the quality of financial statements provide evidence that management in large companies will easily manipulate financial statements due to the weak supervision of the board of commissioners and audit committee so that the financial statements produced will not be in accordance with the circumstances actually and will have an impact on the failure of the objectives of the financial statements. The results of this study support the phenomenon of rampant overstatement by large companies in Indonesia.

Another characteristic of the audit committee is the auditor's competence as measured by education and experience. The test results show that the education and experience of the audit committee do not significantly influence the quality of financial statements. That is, the competence of the audit committee is not a determining factor in the quality of the company's financial statements. The auditor's competency test results do not support previous researchers Dhaliwal, et al. (2006), Marra et al. (2011), Inaam and Khamoussi (2016) which show that the accounting, financial and supervisory competencies of the audit committee have a positive effect on the quality of the published financial statements. 


\section{ENTREPRENEURSHIP AND SUSTAINABILITY ISSUES}

ISSN 2345-0282 (online) http://jssidoi.org/jesi/

2020 Volume 7 Number 3 (March)

http://doi.org/10.9770/jesi.2020.7.3(45)

External auditor quality has a significant positive effect on the quality of financial reporting. The results of this study support previous researchers Johnson et al. (2002), Chen et al. (2010), Ahsen (2011), Soliman and Ragab (2014), Ahmad et al. (2016) which shows that audit quality affects the quality of the company's financial statements. This empirical evidence shows that qualified external auditors can limit opportunistic earnings management. Major companies in Indonesia mostly use the big4 external auditors, as many as 59\% and show the results of a significant influence on the quality of the company's financial statements. External audits conducted with good quality can assure that the audited financial statements are free from material misstatements. Quality external auditors can increase the trust of shareholders and users of financial statements because audits conducted with good quality can assure that the audited financial statements are free from material misstatement so that the published financial statements are believed to have no elements of earnings management practices in particular accrual earnings management.

All control variables, profitability, leverage, and firm age have a significant effect on the quality of the company's financial statements. Testing the quality of financial statements using the Kothari model is consistent with the results of the modified Jones model testing, so the results of this test can be said to be robust.

\section{Conclusion}

Empirical evidence shows that political connections negatively affect the quality of financial reporting. Politically connected companies in Indonesia carry out more aggressive earnings management compared to companies that are not politically connected. The results of this study support the theory of political connection and resource dependence theory. The high transparency of financial statements will show various kinds of provision of subsidies and other special treatments which raise questions of selfish legality that can threaten the stability that has been provided by politicians or bureaucrats so that they do earnings management which causes the integrity of the company's financial statements is low. Political connections also raise the issue of corporate governance in the disclosure and disclosure of information. Empirical evidence shows that the effectiveness of the board of commissioners and audit committee is not effective enough in carrying out the internal monitoring function in the company. These findings support (Bushman, Piotroski et al., 2004; Leuz \& Oberholzer-Gee, 2006) where political influence can contribute to weak corporate governance and weak corporate governance contributing to the low quality of financial reporting (Wright, 1996; Shen \& Chih, 2007; Lara et al., 2007).

The board of commissioners and the audit committee, which should act as a control mechanism of corporate governance, cannot perform their duties as expected because of the political influence that can lead to weak governance structures that better accommodate the interests of the government or politicians (Wati, 2017). The board of commissioners, especially the independent commissioners and audit committees should have the responsibility of ensuring the implementation of the company's strategy goes according to objectives, oversees management in managing the company and requires accountability, but they fail to control management in presenting quality financial reports. They have no ability and cannot demonstrate their independence so they have also failed to represent the interests of other stakeholders other than those of the majority shareholder. CEOs in large companies tend to have greater strength than the board of commissioners. The results of empirical testing also provide evidence that the quality of external audits affects the quality of financial statements. These results indicate that large companies realize the importance of an audit reputation, although, in the end, not a few large companies, which are subject to sanctions due to earnings management cases in the financial statements of companies in Indonesia which have also dragged reputable accounting firms to audit them.

The findings of this study indicate that policymakers must encourage or mandate companies to disclose clearer information about the company's relationship with government, political parties, or politicians so that investors and all interested parties can use this information to better assess the quality of the company's financial 


\section{ENTREPRENEURSHIP AND SUSTAINABILITY ISSUES}

ISSN 2345-0282 (online) http://jssidoi.org/jesi/

2020 Volume 7 Number 3 (March)

http://doi.org/10.9770/jesi.2020.7.3(45)

statements. The results of this study are also expected to be a reference for investors to determine investment preferences in politically connected companies or not. For management, the results of this study are expected to be a consideration in recruiting the board of commissioners and other policies.

The limitation of this study is that it only uses samples from large companies with the reason that they contribute greatly to the capital market and economic growth. Future research is expected to add samples in all categories of companies and compare them with companies in other developing country capital markets.

\section{References:}

Ahmad, L., Suhara, E., \& Ilyas, Y. (2016). The effect of audit quality on earning management within manufacturing companies listed on the Indonesia Stock Exchange. Research Journal of Finance and Accounting, 7(8), 132-138. Retrieved from: https://pdfs.semanticscholar.org/d83d/fd013735b9237fd25e6c236d499f99999532.pdf

Al-dhamari, R., \& Ku Ismail, K. N. I. (2015). Cash holdings, political connections, and earnings quality: Some evidence from Malaysia. International Journal of Managerial Finance, 11(2), 215-231. https://doi.org/10.1108/IJMF-02-2014-0016

Anderson, R. C., dan Reeb, D. M. 2003. Founding-family Ownership and Firm Performance: Evidence from The S\&P 500. The Journal of Finance, 58(3), 1301-1327. https://doi.org/10.1111/1540-6261.00567

Batta, G., Sucre Heredia, R., \& Weidenmier, M. (2014). Political connections and accounting quality under high expropriation risk. European Accounting Review, 23(4), 485-517. https://doi.org/10.1080/09638180.2014.906316

Beasley, M. S. 1996. An Empirical Analysis of the Relation between The Board of Director Composition And Financial Statement Fraud. Accounting Review, 443-465. Retrieved from: https://www.jstor.org/stable/248566?seq=1\#page_scan_tab_contents

Bedard, J., Chtourou, S. M., \& Courteau, L. (2004). The effect of audit committee expertise, independence, and activity on aggressive earnings management. Auditing: A Journal of Practice \& Theory, 23(2), 13-35.

Bradbury, M., Mak, Y. T., \& Tan, S. M. (2006). Board characteristics, audit committee characteristics and abnormal accruals. Pacific accounting review, 18(2), 47-68. https://doi.org/10.1108/01140580610732813

Brick, I. E., \& Chidambaran, N. K. (2010). Board meetings, committee structure, and firm value. Journal of corporate finance, 16(4), 533553 .

Bryan, D., Liu, C., \& Tiras, S. L. (2004). The influence of independent and effective audit committees on earnings quality. Available at SSRN, 488082.

Cadbury, A. (1995). Committee on the financial aspects of corporate governance: Compliance with the code of best practice. Gee, London. Retrieved from: https://www.sciencedirect.com/science/article/pii/S0890838900901471

Challen, D. (2011). Quarter Century in Financial Accountability: Scrutiny through Transparency. Public Administration Today, (26), 55. Retrieved from: https://search.informit.com.au/documentSummary; dn=229236740813521;res=IELAPA

Chen, H., Tang, Q., Jiang, Y., \& Lin, Z. (2010). The role of international financial reporting standards in accounting quality: Evidence from the European Union. Journal of international financial management \& accounting, 21(3), 220-278. https://doi.org/10.1111/j.1467$\underline{646 X .2010 .01041 . X}$

Chaney, P. K., Faccio, M., \& Parsley, D. (2011). The quality of accounting information in politically connected firms. Journal of Accounting and Economics, 51(1-2), 58-76. https://doi.org/10.1016/j.jacceco.2010.07.003

Chen, S., Sun, S. Y., \& Wu, D. (2010). Client importance, institutional improvements, and audit quality in China: An office and individual auditor level analysis. The Accounting Review, 85(1), 127-158. https://doi.org/10.2308/accr.2010.85.1.127

Chi, H. Y., Weng, T. C., Chen, G. Z., \& Chen, S. P. (2019). Do Political Connections Affect the Conservative Financial Reporting of Family Firms?. Sustainability, 11(20), 5563. https://doi.org/10.3390/su11205563

Chtourou, S. M., Bedard, J., \& Courteau, L. (2001). Corporate governance and earnings management. Retrieved from https://papers.ssrn.com/id275053.pdf

Dhaliwal, D. S., Naiker, V., \& Navissi, F. (2006). Audit committee financial expertise, corporate governance and accruals quality: An empirical analysis. Corporate Governance and Accruals Quality: An Empirical Analysis (May 2006). Retrieved from: https://papers.ssrn.com/sol3/papers.cfm?abstract id=906690 


\section{ENTREPRENEURSHIP AND SUSTAINABILITY ISSUES}

ISSN 2345-0282 (online) http://jssidoi.org/jesi/

2020 Volume 7 Number 3 (March)

http://doi.org/10.9770/jesi.2020.7.3(45)

Dechow, P. M., Sloan, R. G., \& Sweeney, A. P. (1996). Causes and consequences of earnings manipulation: An analysis of firms subject to enforcement actions by the SEC. Contemporary accounting research, 13(1), 1-36. https://doi.org/10.1111/j.1911-3846.1996.tb00489.x

Di Donato, F., \& Fiori, G. (2012). The relation between earnings management independent directors and audit committee: A study of Italian listed companies. Available at SSRN 1991232. http://dx.doi.org/10.2139/ssrn.1991232

Faccio, M., Masulis, R. W., \& McConnell, J. J. (2006). Political connections and corporate bailouts. The Journal of Finance, 61(6), 25972635. https://doi.org/10.1111/j.1540-6261.2006.01000.x

Faccio, M., 2006. Politically connected firms. American Economic Review, 96(1), pp.369-386. https://doi.org/10.1257/000282806776157704

Faccio, M. (2010). Differences between politically connected and nonconnected firms: A cross-country analysis. Financial management, 39(3), 905-928. https://doi.org/10.1111/j.1755-053X.2010.01099.x

Fan, J. P., Wong, T. J., \& Zhang, T. 2007. Politically Connected Ceos, Corporate Governance, and Post-IPO Performance of China's Newly Partially Privatized Firms. Journal of Financial Economics, 84(2), pp. 330-357. https://doi.org/10.1016/j.jfineco.2006.03.008

Francis, B. B., Hasan, I., \& Sun, X. (2009). Political connections and the process of going public: Evidence from China. Journal of International Money and Finance, 28(4), 696-719. https://doi.org/10.1016/j.jimonfin.2009.01.002

Hermawan, AA. .and Adinda, G, 2012. The Effect of Board Characteristics and Audit Committee Existence on Earnings Quality of Indonesian State-Owned Enterprises. Retrieved from SSRN: https://ssrn.com/abstract=2135051 or http://dx.doi.org/10.2139/ssrn.2135051

Habib, A., Ranasinghe, D., Muhammadi, A. H., \& Islam, A. (2018). Political connections, financial reporting and auditing: Survey of the empirical literature. Journal of International Accounting, Auditing and Taxation, 31, 37-51. https://doi.org/10.1016/j.intaccaudtax.2018.05.002

Inaam, Z., \& Khamoussi, H. (2016). Audit committee effectiveness, audit quality and earnings management: a meta-analysis. International Journal of Law and Management, 58(2), 179-196. https://doi.org/10.1108/IJLMA-01-2015-0006

Jacoby, G., Li, J., \& Liu, M. (2019). Financial distress, political affiliation and earnings management: the case of politically affiliated private firms. The European Journal of Finance, 25(6), 508-523. https://doi.org/10.1080/1351847X.2016.1233126

Lara, J. M.G., Osma, B. G., \& Penalva, F. (2007). Board of directors' characteristics and conditional accounting conservatism: Spanish evidence. European Accounting Review, 16(4), 727-755.

Leuz, C., Nanda, D., \& Wysocki, P. D. (2003). Earnings management and investor protection: an international comparison. Journal of Financial Economics, 69(3), 505-527. https://doi.org/10.1016/S0304-405X(03)00121-1

Leuz, C. and Oberholzer-Gee, F. 2006. Political relationships, global financing, and corporate transparency: Evidence from Indonesia. Journal of Financial Economics, 81(2), pp.411-439. https://doi.org/10.1016/j.jfineco.2005.06.006

Lincényi, M., Čársky, J. 2020. Policy trusts in public policy in the Slovak Republic. Insights into Regional Development, 2(1), 456-468. http://doi.org/10.9770/IRD.2020.2.1(5)

Klein, A. (2002). Audit committee, a board of director characteristics, and earnings management. Journal of Accounting and Economics, 33(3), 375-400. https://doi.org/10.1016/S0165-4101(02)00059-9

Marra, A., Mazzola, P., \& Prencipe, A. (2011). Board monitoring and earnings management pre-and post-IFRS. The International Journal of Accounting, 46(2), 205-230. https://doi.org/10.1016/j.intacc.2011.04.007

Mobarak, A. M., \& Purbasari, D. (2005). Political trade protection in developing countries: firm-level evidence from Indonesia. Available at SSRN 770949. https://dx.doi.org/10.2139/ssrn.770949

Mohammed, N. F., Ahmed, K., \& Ji, X. D. (2017). Accounting conservatism, corporate governance and political connections. Asian Review of Accounting, 25(2), 288-318. https://doi.org/10.1108/ARA-04-2016-0041

Norwani, N. M., Zam, Z. M., \& Chek, I. T. (2011). Corporate governance failure and its impact on financial reporting within chosen companies. International Journal of Business and Social Science, 2(21). Retrieved from:

http://ijbssnet.com/journals/Vol_2_No_21_Special_Issue_November_2011/23.pdf

Piotroski, J. D., Wong, T. J., \& Zhang, T. (2010). Political incentives to suppress negative financial information: Evidence from statecontrolled Chinese firms. Unpublished working paper. Stanford University, Chinese University of Hong Kong, and the City University of Hong Kong. Retrieved from: https://care-mendoza.nd.edu/assets/152221/piotroski2009.pdf 


\section{ENTREPRENEURSHIP AND SUSTAINABILITY ISSUES}

ISSN 2345-0282 (online) http://jssidoi.org/jesi/

2020 Volume 7 Number 3 (March)

http://doi.org/10.9770/jesi.2020.7.3(45)

Qinghua, W. U., Pingxin, W. A. N. G., \& Junming, Y. I. N. (2007). Audit committee, board characteristics and quality of financial reporting: An empirical research on the Chinese securities market. Frontiers of Business Research in China, 1(3), 385-400. https://doi.org/10.1007/s11782-007-0023-y

Shleifer, Andrei dan Robert W, Vishny. 1994. Politicians and Firms, Quarterly Journal of Economics, 995-1025. https://doi.org/10.2307/2118354

Soliman, M. M., \& Ragab, A. A. (2014). Audit committee effectiveness, audit quality and earnings management: an empirical study of the listed companies in Egypt. Research Journal of Finance and Accounting, 5(2), 155-166. Retrieved from: https://s3.amazonaws.com/academia.edu.documents/31769175/Audit_Committee_Effectiveness_1_.pdf?

Tian, L., \& Cheung, W. (2013). Political connections, controlling shareholders and post-IPO performance of China's listed companies. Retrieved from: https://web.iss.u-tokyo.ac.jp/kyoten/activities/paper April24th.pdf

Uadiale, O. M. (2010). The impact of board structure on corporate financial performance in Nigeria. International Journal of Business and Management, 5(10), 155. Retrieved from:

https://www.researchgate.net/profile/Olayinka_Uadiale/publication/46302805_The_Impact_of_Board_Structure_on_Corporate_Financial_ Performance_in_Nigeria/links/004635362b6ff526e7000000.pdf

Veronica, S., \& Bachtiar, Y. S. (2005). Corporate governance, information asymmetry, and earnings management. Jurnal Akuntansi dan Keuangan Indonesia, 2(1), 77-106.

Wang, Z., Chen, M. H., Chin, C. L., \& Zheng, Q. (2017). Managerial ability, political connections, and fraudulent financial reporting in China. Journal of Accounting and Public Policy, 36(2), 141-162. https://doi.org/10.1016/j.jaccpubpol.2017.02.004

Wati, L.N., Rachmat Sudarsono, S.E., Si, M. and Erie Febrian, S.E. 2016a. Corporate governance on conglomerates politically connected. International Journal of Business, Economics and Law, 10(1), pp.23-31. http://doi.org/10.9770/jesi.2019.7.1(5)

Wati, L.N., Primiana, I. and Sudarsono, R. 2016b. Political connections of conglomerates: evidence from Indonesia Stock Exchange. Actual Problems of Economics, (12), pp.110-119. Wati, L. N. 2017. Board of commissioner's effectiveness on politically connected conglomerates: Evidence from Indonesia. Pertanika Journal Social Sciences \& Humanities, 25(S), pp. 255-270. Retrieved from: http://www.pertanika.upm.edu.my/view_archives.php?journal=JSSH-25-S-11

Wati, L. N. 2017. Board of commissioner's effectiveness on politically connected conglomerates: Evidence from Indonesia. Pertanika Journal Social Sciences \& Humanities, 25(S), pp. 255-270. Retrieved from: http://www.pertanika.upm.edu.my/view archives.php?journal=JSSH-25-S-11

Watkins, A. L., Hillison, W., \& Morecroft, S. E. (2004). Audit quality: A synthesis of theory and empirical evidence. Journal of accounting literature, 23, 153. https://search.proquest.com/openview/848c22290cbd79f08e07f1a6a491974d/1 ?pq-origsite=gscholar\&cbl=31366

Watts, R. Zimmerman. 1986. Positive accounting theory, 318-352.

Wu, W., Wu, C., Zhou, C., dan Wu, J. 2012. Political connections, tax benefits and firm performance: Evidence from China. Journal of Accounting and Public policy, 31(3), 277-300. https://doi.org/10.1016/j.jaccpubpol.2011.10.005

Xie, B., Davidson III, W. N., \& DaDalt, P. J. (2003). Earnings management and corporate governance: the role of the board and the audit committee. Journal of Corporate Finance, 9(3), 295-316.

Yao, L. J., McGee, R. W., \& Yuan, X. (2012). Corporate governance and the timeliness of financial reporting: a comparative study of the People's Republic of China, the USA and the European Union. Journal of Asia Business Studies.

https://doi.org/10.1108/15587891211190679

Yen, S. C. (2013). What causes fraudulent financial reporting? Evidence-based on H shares. Emerging Markets Finance and Trade, 49(sup4), 254-266. https://doi.org/10.2753/REE1540-96X4905S417

You, J., \& Du, G. (2012). Are political connections a blessing or a curse? Evidence from CEO turnover in China. Corporate Governance: An International Review, 20(2), 179-194. https://doi.org/10.1111/j.1467-8683.2011.00902.x 


\section{ENTREPRENEURSHIP AND SUSTAINABILITY ISSUES}

ISSN 2345-0282 (online) http://jssidoi.org/jesi/

2020 Volume 7 Number 3 (March)

http://doi.org/10.9770/jesi.2020.7.3(45)

\section{Acknowledgements}

This research was supported by the project, which has received funding from the Directorate of General for Strengthening Research and Development, the Ministry of Research and Technology Republic Indonesia. Great thanks to DP2M DIKTI of Ministry of Research And Technology Republic Indonesia with the research grant contract number, i.e. 5/AKM/PNT/2019, Thank you to Sekolah Tinggi Ilmu Ekonomi (STIE) Muhammadiyah Jakarta Indonesia for the support and assistance in this research.

Dr. Lela Nurlaela WATI, MM is an Associate Professor of STIE Muhammadiyah Jakarta, Indonesia. She is currently reviewer a National and International Journal. Her publication has appeared in various international journals, such as Entrepreneurship and Sustainability Issues, Pertanika Journal of Social Sciences and Humanities, Actual Problems of Economics, Internatioanal Journal of Business Economics and Law, South East Asia Journal of Business Economics and Law.

ORCID ID: https://orcid.org/0000-0001-7046-612X

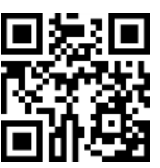

Dr RAMDANY, SE. Ak., M.Ak. C.P.A is an Assistant Professor of STIE Muhammadiyah Jakarta, Indonesia. He is currently reviewer a National Journal. Her publication has appeared in various National and International journals, such as International Journal of Business Economics and Law, Risk Governance and Control: Financial Markets \& Institutions, Ekobis Journal, and Accounting Journal.

ORCID ID: https://orcid.org/0000-0001-6707-3704

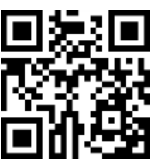

MOMON, SE. Ak., M.Ak. CRMP is Lecturer of STIE Muhammadiyah Jakarta and Dep. General Manager Auditor at PT. Sompo Indonesia.

ORCID ID: https://orcid.org/0000-0003-0338-6677

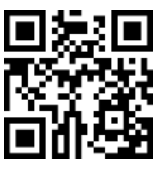

Register for an ORCID ID:

https://orcid.org/register

Copyright (C) 2020 by author(s) and VsI Entrepreneurship and Sustainability Center

This work is licensed under the Creative Commons Attribution International License (CC BY).

http://creativecommons.org/licenses/by/4.0/

\section{CC) (7) Open Access}

